\title{
PERBANDINGAN TRANSPARANSI DAN AKUNTABILITAS PENGELOLAAN DANA ZAKAT PADA LEMBAGA ZAKAT
}

\section{TRANSPARENCY AND ACCOUNTIBILITY ZAKAT FUND MANAGEMENT COMPARATION IN ZAKAT'S INSTITUTION}

\author{
D. Lilianita1 ${ }^{1}$, . Muchlisin ${ }^{2}$ \\ 1Program Studi Ekonomi Islam Fakultas Ekonommi Islam Universitas Djuanda, Jl. Tol Ciawi No. 1, \\ Kotak Pos 35 Bogor 16720 \\ 2Program Studi Ekonomi Islam Fakultas Ekonommi Islam Universitas Djuanda, Jl. Tol Ciawi No. 1, \\ Kotak Pos 35 Bogor 16720
}

\begin{abstract}
This study aims to find out how the Amil Zakat Agency (BAZ) and the Amil Zakat Institution (LAZ) in the Bogor region apply the principles of transparency and accountability and know what differences are made by BAZ and LAZ in the application of transparency and accountability in managing zakat funds. The method used is descriptive quantitative. Primary data in this study were in the form of questionnaires and interview results, and for secondary data in this study were financial data obtained from each institution. Based on the results of the study there is no significant difference in the value of the application of transparency between the BAZNAS of Bogor City and dt-Care. Whereas for the implementation of accountability that there is no significant difference in the value of accountability between the BAZNAS of Bogor City and DT-Peduli.
\end{abstract}

Keywords: Comparison, Transparency, Accountability and Management of Zakat Funds

\begin{abstract}
ABSTRAK
Perbandingan transparansi dan akuntabilitas pengelolaan dana zakat pada lembaga zakat "Studi Kasus2 Lembaga Zakat di Wilayah Bogor". Penelitian ini bertujuan untuk mengetahui bagaimana Badan Amil Zakat (BAZ) dan Lembaga Amil Zakat (LAZ) di wilayah Bogor menerapkan prinsip transparansi dan akuntabilitas serta mengetahui perbedaan apa saja yang dilakukan oleh BAZ dan LAZ dalam penerapan transparansi dan akuntabilitas pengelolaan dana zakat. Metode yang digunakan yaitu deskriptif kuantitatif. Data primer pada penelitian ini berupa hasil kuesioner dan hasil wawancara, dan untuk data sekunder pada penelitian ini berupa data keuangan yang diperoleh dari masing-masing lembaga. Berdasarkan hasil penelitian, untuk penerapan transparansi adalah tidak terdapat perbedaan yang signifikan pada nilai penerapan transparansi antara BAZNAS Kota Bogor dan dt-Peduli. Sedangkan untuk penerapan akuntabilitas juga tidak terdapat perbedaan yang signifikan pada nilai akuntabilitas antara BAZNAS Kota Bogor dan dt-Peduli.
\end{abstract}

Kata Kunci: Perbandingan, Transparansi, Akuntabilitas dan Pengelolaan Dana Zakat

Lilianita, Debinair. 2019. Perbandingan Transparansi dan Akuntabilitas Pengelolaan Dana Zakat Pada Lembaga Zakat (Studi Kasus 2 Lembaga Zakat di Wilayah Bogor). Jurnal Syarikah 5(1): 82-93. 


\section{PENDAHULUAN}

Bogor merupakan salah satu wilayah yang memiliki jumlah ummat muslim yang cukup banyak. Menurut Badan Pusat Statistik (BPS Kota Bogor) pada tahun 2015 jumlah penduduk Kota Bogor tahun 2014 sebesar 1.030 .720 jiwa sedangkan jumlah penduduk muslim yang terdapat di Bogor sejumlah 944.042 jiwa atau sebesar 91\% dari total populasi yang ada. Fakta ini menggambarkan bahwa wilayah Bogor memiliki potensi zakat yang cukup besar.

Potensi zakat yang dimiliki oleh wilayah Bogor menurut BAZNAS Kota Bogor pada tahun 2017 ialah sebesar 102 miliar rupiah. Namun, pada tahun 2016 yang lalu penerimaan zakat baru terealisasikan sebesar 4,7 miliar, jumlah tersebut melebihi angka yang ditargetkan yakni 3,7 miliar. Meski begitu, angka ini masih sangat jauh dari potensi nilai zakat masyarakat Bogor. Hal ini menunjukan bahwa terdapat kesenjangan yang cukup tinggi antara potensi zakat dengan penghimpunan dana zakatnya. Hadirnya beberapa lembaga zakat diharapkan mampu meningkatkan pertumbuhan jumlah dana zakat yang terealisasi di wilayah Bogor agar mampu mencapai potensinya.

Terdapat beberapa hal yang mengakibatkan rendahnya pengumpulan dana zakat yang ada di wilayah Bogor dan belum mencapai potensi yang seharusnya. Salah satu alasan utama terjadinya ketimpangan antara potensi dana zakat dengan realisasinya yaitu masih banyaknya muzakki yang membayarkan zakatnya secara langsung kepada mustahik dan tidak melalui lembaga zakat (Huda \& Tjiptohadi 2013 : 376). Hal lainnya yang menghambat terealisasikannya dana zakat dengan baik yaitu kurang pahamnya ummat muslim sendiri mengenai zakat dan adanya sikap kurang percaya masyarakat terhadap para penyelenggara zakat (Hermawan \& Gianti, 2010 : 34-35).

Lembaga Pengelola Zakat (LPZ) secara profesional seharusnya mengelola dan menjalankan segala bentuk kegiatannya sesuai dengan ketentuan-ketentuan syariah dan tidak boleh keluar dari ketetapan syariat yang ada, mulai dari perhitungan, pengumpulan dan pendistribusian dana zakat. Semua ketentuan mengenai zakat harus diatur secara syariat Islam, menuntut sebuah Lembaga Pengelola Zakat harus akuntabel dan transparan (Nikmatunayah, 2015 : 486). Sehingga semua pihak yang memiliki kontribusi kepada Lembaga Pengelola Zakat dapat mengamati dan mengontrol secara langsung, dan dengan adanya transparansi dan akuntabilitas pada laporan keuangan di suatu Lembaga Pengelola Zakat dapat mempengaruhi adanya kepuasan dari muzakki (Fitri dan Asma, 2016 : 207).

Lembaga pengelola zakat merupakan salah satu organisasi yang memiliki tugas untuk mengelola dana publik, dan perlu menerapkan prinsip Good Corporate Governance (GCG) karena pada prinsip ini meliputi accountability, democratic, responsibility, dan rule of the law. Pengelolaan yang dilakukan oleh lembaga zakat harus dilaksanakan secara transparan dan akuntabel, karena berkaitan dengan publik (Maani, 2009: 42). Hal inilah yang mendasari Lembaga Pengelola Zakat harus menerapkan prinsip ini, karena dengan terlaksananya segala bentuk kegiatan yang ada pada Lembaga Pengelola Zakat secara transparan dan akuntabel, khususnya mengenai pelaporan keuangan akan meningkatkan tingkat kepercayaan yang ada pada masyarakat. Pelaporan keuangan yang dilakukan oleh Lembaga Pengelola Zakat biasanya dipresentasikan pada sebuah laporan keuangan.

\section{MATERI DAN METODE}

Jenis penelitian yang akan digunakan adalah analisis deskriptif kuantitatif. 
Metode penelitian kuantitatif menurut (Sugiyono, 2015: 8) adalah metode penelitian yang berlandaskan pada filsafat positivisme, yang digunakan untuk meneliti populasi atau sampel, pengumpulan data menggunakan instrumen penelitian, analisis data bersifat kuantitatif/statistik, dengan tujuan yaitu untuk menguji hipotesis yang telah ditentukan. Sedangkan penelitian deskriptif menurut (Nazir, 2011 : 54) merupakan salah satu metode yang dapat dilakukan oleh seorang peneliti untuk meneliti status sekelompok manusia, objek, kondisi, sistem pemikiran atau bahkan suatu kelas peristiwa pada masa sekarang.

Penelitian ini dimaksudkan untuk dapat menggambarkan dan memberikan keterangan-keterangan mengenai bagaimana penerapan transparansi dan akuntabilitas pada pengelolaan dana zakat di BAZ dan LAZ Wilayah Bogor. Penelitian ini juga bermakud untuk mengetahui ada atau tidak nya perbedaan dari penerapan transparansi dan akuntabilitas di BAZ dan LAZ wilayah Bogor.

Populasi menurut (Sugiyono, 2015: 80) adalah suatu wilayah generalisasi yang terdiri atas: obyek atau subyek yang memiliki kualitas dan karakteristik tertentu yang telah ditetapkan oleh peneliti untuk dipelajari dan kemudian dapat ditarik kesimpulannya. Populasi dalam penelitian ini adalah lembaga zakat di wilayah Bogor, baik lembaga zakat yang dikelola oleh pemerintah maupun lembaga zakat yang dikelola oleh swasta. Sedangkan sampel menurut (Nazir, 2011 : 190) merupakan bagian dari populasi yang telah ditentukan.

Sampel adalah suatu prosedur yang dimana hanya sebagian dari populasi saja yang akan digunakan untuk peneliti dapat menentukan sifat dan ciri yang dikehendaki dari populasi yang ada. Sedangkan menurut (Sugiyono, 2015: 61) sampel merupakan bagian dari jumlah dan karakteristik yang dimiliki oleh populasi tersebut. Sampel dari penelitian ini adalah Badan Amil Zakat Nasional (BAZNAS) Kota Bogor dan Lembaga Amil Zakat Dompet Peduli Ummat Daarut Tauhiid (DPU-DT).

Data yang digunakan dalam penelitian ini adalah data yang bersifat kuantitatif karena dinyatakan dengan angka yang nantinya akan menunjukkan nilai terhadap besaran atas variabel yang diwakilinya. Jenis data yang akan digunakan dalam penelitian ini adalah data primer dan data sekunder.

Teknik Analisis Data

Teknik analisis data yang akan digunakan dalam melakukan penelitian akan dilaksanakan dalam beberapa tahap yaitu:

\section{Statistik Deskriptif}

Statistik deskriptif merupakan salah satu metode yang dapat digunakan untuk menganalisis data kuesioner yang telah diisi oleh para responden dengan mencari nilai rata-rata pada tabel, sehingga akan diperoleh hasil persentase dari masingmasing pertanyaan. Adapun rumus yang digunakan dalam perhitungan dalam perhitungan ini adalah:

$$
\mathrm{P}=(\mathrm{f} / \mathrm{n}) \times 100 \%
$$

Keterangan:

$\mathrm{P}=$ Persentase

$\mathrm{F}=$ Frekwensi dari jawaban yang dipilih responden

$$
\mathrm{N}=\text { Jumlah responden }
$$

Adapun skor yang diberikan adalah mulai dari 5, 4, 3, 2, 1 . Pengukurannya sendiri terdiri atas:
a. Sangat setuju (SS) $\quad=5$
b. Setuju (S) $=4$
c. Kurang setuju (KS) $=3$
d. Tidak setuju $=2$
e. Sangat tidak setuju (STS) $=1$

2. Uji Normalitas Data

Uji normalitas data digunakan untuk mengetahui apakah data yang diperoleh berdistribusi normal atau tidak. Untuk mengetahui 
normalitasnya digunakanlah metode Lifiefors dengan taraf signifikan 5\%. Pengujian dilakukan dengan bantuan SPSS. Uji normalitas yang digunakan dalam peneltian ini adalah Kolmogorov-Smirnov yang besarnya dapat dihitung dengan menggunakan program SPSS.

1) Hipotesis yang diuji adalah:

a) $\mathrm{H}_{0}$ : sampel berasal dari populasi berdistribusi normal

b) $\mathrm{H}_{1}$ : sampel tiidak berasal dari populasi berdistribusi normal

2) Taraf signifikan $a=0,05$

a) Jika probabilitas atau signifikan yang diperoleh $>a$, maka sampel berasal dari populasi yang berdistribusi normal.

b) Jika probabilitas atau signifikan yang diperoleh < a, maka sampel bukan berasal dari populasi yang berdistribusi normal.

3. Uji Homogenitas Varian

Uji homogenitas digunakan untuk mengetahui ada atau tidaknya perbedaan variansi antara kelompok yang diuji, yaitu penerapan transparansi dan akuntabilitas pengelolaan dana zakat pada 2 lembaga zakat di wilayah Bogor, diantaranya: BAZNAS Kota Bogo . Uji homogenitas dilakukan dengan menggunakan metode Barlet dengan taraf signifikan 5\%.

Uji homogenitas dalam penelitian ini dilakukan dengan menggunakan Uji Levene's yang besarnya dapat dihitung dengan komputer melalui program SPSS.

1) Hipotesis yang diuji adalah:

a) $\mathrm{H}_{0}$ : variansi pada tiap kelompok sama (homogen).

b) $\mathrm{H}_{1}$ : variansi pada tiap kelompok tidak sama (tidak homogen).

2) Taraf signifikansi $a=0,05$ a) Jika probabilitas atau signifikan yang diperoleh $>a$, maka variansi setiap sampel sama (homogen).

b) Jika probabilitas atau signifikan yang diperoleh $<\mathrm{a}$, maka variansi setiap sampel tidak sama (homogen).

\section{Uji Beda}

Dalam penelitian ini uji T-Test Independent untuk mengidentifikasikan perbedaan penerapan transparansi dan akuntabilitas pengelolaan dana zakat antara BAZNAS Kota Bogor dan dt-Peduli. Sebelum dilakukan uji T-test Independent dilakukan terlebih dahulu uji normalitas data. Karena data berdistribusi normal, selanjutnya dilakukan uji homogenitas atau varian dengan uji F-Test atau Levene's Test.

Dalam penelitian ini, kedua kelompok data mempunyai varian yang sama sehingga nilai uji T-test Independent dibaca pada Equaal variance. Rumus manual uji homogenitas varian adalah sebagai berikut:

$$
\mathrm{F}=\frac{S_{1}^{2}}{S_{2}{ }^{2}} \begin{aligned}
& \text { KETERANGAN } \\
& \mathrm{F}=\text { Nilai } \mathrm{F} \text { hitung } \\
& \mathrm{S}_{1}^{2}=\text { Nilai varian terbesar } \\
& \mathrm{S}_{2}^{2}=\text { Nilai varian terkecil }
\end{aligned}
$$

Data dinyatakan memiliki varian yang sama (equal variance) bila $\mathrm{F}$ Hitung < F-Tabel, dan sebaliknya, varian data dinnyatakan tidak sama (unequal variance) bila F-Hitung > FTabel. Bentuk varian kedua kelompok data akan berpengaruh pada nilai standar error yang akhirnya akan membedakan rumus pengujiannya.

Uji t untuk varian yang sama (equal variance) menggunakan rumus manual Polled Varians:

$$
t=\frac{\bar{X}_{1}-\bar{X}_{2}}{\sqrt{\frac{\left(n_{1}-1\right) S_{1}^{2}+\left(n_{2}-1\right) S_{2}^{2}}{n_{1}+n_{2}-2}\left(\frac{1}{n_{1}}+\frac{1}{n_{2}}\right)}}
$$


Uji t untuk varian yang berbeda (unequal variance) menggunakan rumus manual Separated Varians dibawah ini:

$$
t=\frac{\bar{X}_{1}-\bar{X}_{2}}{\sqrt{\frac{S_{1}^{2}}{n_{1}}+\frac{S_{2}^{2}}{n_{2}}}}
$$

Keterangan:

$$
\begin{array}{ll}
\mathrm{n} 1 & \text { : Jumlah sampel } 1 . \\
\mathrm{n} 2 & \text { : Jumlah sampel } 2 . \\
\mathrm{x} 1 & \text { : Rata-rata sampel ke-1. } \\
\mathrm{x} 2 & \text { : Rata-rata sampel ke-2. } \\
\text { s1 } & \text { : Varians sampel ke-1. } \\
\text { s2 } & \text { : varians sampel ke } 2 .
\end{array}
$$

\section{HASIL DAN PEMBAHASAN}

Laporan Keuangan Lembaga

\section{Badan Amil Zakat Nasional (BAZNAS) Kota Bogor}

BAZNAS Kota Bogor menghimpun dana zakat di tahun 2015 sebesar Rp. $2,756,732,272$ dan mengalami peningkatan yang cukup besar di tahun 2016 yaitu sebesar Rp. $4,353,367,919$, namun di tahun 2017 penghimpunan dana zakat di BAZNAS kota Bogor tidak mengalami peningkatan yang cukup baik. Tahun 2017 dana yang diperoleh mengalami penurunan dari tahun 2016 ke tahun 2017 yaitu sebesar Rp. 4,131,236,822.

Pengeluran BAZNAS kota Bogor untuk biaya layanan muzakki di tahun 20152016 meningkat sebesar Rp. $58,618,575$ setara dengan $2 \%$. Kemudian di tahun 2016-2017 pengeluaran yang dilakukan oleh BAZNAS kota Bogor juga mangalami kenaikan yakni sebesar Rp. $1,822,731,531$ setara dengan $72 \%$. Akan tetapi, meskipun pengelurannya cukup besar BAZNAS kota Bogor tidak mengalami defisit, dikarenakan adanya dana yang tersisa di tahun 2016 sebesar Rp. 2,273,862,161.00.

2. Daarut Tauhid Peduli (dt-Peduli)
Daarut Tauhid Peduli (dt-Peduli) menghimpun dana zaka di tahun 2015 sebesar Rp. $1,047,458,946.00$. Tahun 2016 dana yang diterima oleh dtPeduli meningkat sebesar Rp. 1,466,191,588.00. Kemudian di tahun 2017 penghimpunan dana zakat yang terdapat di dt-Peduli mengalami penurunan sebesar Rp. 1,178,063,129.00.

Pengeluran dt-Peduli cabang Bogor untuk biaya layanan muzakki di tahun 2015-2016 menurun sebesar $R$. $176,662,458.00$ setara dengan $-20 \%$. Pada tahun 2016-2017 pengeluaran yang dilakukan oleh dt-Peduli mangalami peningkatan sebesar $R p$. $693,057,619$ setara dengan $98 \%$. Akan tetapi, meskipun pengelurannya cukup besar dt-Peduli tidak mengalami defisit, dikarenakan adanya dana yang tersisa di tahun 2016 sebesar Rp. 762,449,551.00.

\section{Analisis Deskriptif Kuantitatif}

Berdasarkan pada teknik pengumpulan data yang telah ditentukan oleh peneliti, untuk memperoleh data dalam menganalisis penelitian ini, telah diajukan beberapa kuesioner kepada beberapa muzaki dari kedua lembaga zakat yang sudah ditentukan yaitu BAZNAS Kota Bogor dan dt-Peduli.

Pengajuan kuesioner ini dilakukan dengan tujuan untuk memperoleh data secara jelas dari para responden dari berbagai aspek. Selain itu, terdapat beberapa variabel yang wajib diisi oleh para responden. Dengan demikian, peneliti akan mendapatkan hasil penelitian yang diperoleh dari jawaban responden melalui kuesioner, sehingga peneliti dapat membuat kesimpulan yang akurat. Adapun jumlah kuesioner yang telah diberikan kepada responden yaitu 20 kuesioner untuk masing-masing muzaki dari kedua lembaga yang ditentukan.

Analisis Data Demografi Responden Demografi Jenis Kelamin 
Setelah seluruh kuesioner diisi oleh para responden dari masing-masing jenis kelamin responden, baik laki-laki maupun perempuan. Dari 20 kuesioner yang telah terisi untuk muzaki atau responden BAZNAS Kota Bogor, 6 kuesiner diisi oleh responden dengan jenis kelamin laki-laki, sedangkan 14 kuesioner diisi oleh responden perempuan. Pada dt-Peduli Dari 20 kuesioner yang telah terisi, 8 kuesiner diisi oleh responden dengan jenis kelamin laki-laki, sedangkan 12 kuesioner diisi oleh responden perempuan.

Jumlah responden atau muzaki didominasi oleh perempuan. Pada dasarnya, jenis kelamin laki-laki atau perempuan tidak menjadi syarat utama untuk menjadi muzaki.

\section{Demografi Pendidikan Terakhir Responden}

Berdasarkan data kuisioner yang diberikan kepada responden diketahui bahwa tingkat pendidikan dari 20 responden BAZNAS Kota Bogor, terdapat sebanyak 7 orang responden (35\%) dengan tingkat pendidikan SMA, 13 orang responden (65\%) dengan tingkat pendidikan S1. Dari data tersebut penulis dapat memberikan gambaran bahwa, tingkat pendidikan paling tinggi dari seluruh responden adalah tingkat pendidikan S1 untuk responden (muzakki) di BAZNAS Kota Bogor.

Sedangkan untuk dt-Peduli terdapat sebanyak 16 orang responden (80\%) dengan tingkat pendidikan SMA, 4 orang responden (20\%) dengan tingkat pendidikan S1. Dari data tersebut dapat memberikan gambaran bahwa, tingkat pendidikan paling tinggi dari seluruh responden adalah tingkat pendidikan SMA untuk responden (muzakki) di dtPeduli.

\section{Demografi Usia Responden}

Berdasarkan hasil penelitian yang diperoleh dari dari masing-masing 20 responden yang terdapat pada BAZNAS Kota Bogor terdapat 7 orang (35\%) responden dengan rentan usia 17-24 tahun, 8 orang $(40 \%)$ responden dengan rentan usia 25 - 34 tahun, 5 orang (25\%) responden dengan rentan usia 35 - 49 tahun. Dari data tersebut penulis dapat memberikan gambaran bahwa, usia 25-34 memiliki jumlah responden terbanyak, dan untuk usia 35-49 memiliki jumlah responden yang paling sedikit untuk responden (muzakki) di BAZNAS Kota Bogor.

Sedangkan pada dt-Peduli terdapat 5 orang $(25 \%)$ responden dengan rentan usia 17-24 tahun, 9 orang (45\%) responden dengan rentan usia 25 - 34 tahun, 6 orang (30\%) responden dengan rentan usia 35 - 49 tahun. Dari data tersebutdapat disimpulkan bahwa, usia 25-34 memiliki jumlah responden terbanyak, dan untuk usia 35-49 memiliki jumlah responden yang paling sedikit untuk responden (muzakki) di dt-Peduli.

\section{Pilihan Institusi Pengelolaan Dana Zakat}

Berdasarkan jawaban muzaki dari BAZNAS Kota Bogor mengenai pilihan pertama dalam membayar zakat ke lembaga zakat khususnya BAZNAS Kota Bogor. Jawaban sangat setuju berjumlah 2 orang dengan persentase $10 \%$, muzaki yang setuju berjumlah 17 orang dengan persentase $85 \%$, dan masyarakat yang kurang setuju berjumlah 1 orang dengan persentase $5 \%$. Hasil perhitungan skala likert diperoleh angka kriteia penafsiran sebesar M=4,05 dari hasil ini menunjukan bahwa responden rata-rata "setuju" responden memilih BAZNAS Kota Bogor sebagai lembaga zakat pertama yang akan dituju ketika ingin membayar zakat.

Sedangkan jawaban muzaki dari dtPeduli mengenai pilihan pertama dalam membayar zakat ke lembaga zakat khususnya dt-Peduli. Jawaban sangat setuju berjumlah 4 orang dengan persentase $20 \%$, muzaki yang setuju berjumlah 16 orang dengan persentase 80\%. Hasil perhitungan skala likert diperoleh angka kriteia penafsiran 
sebesar M=4,20 dari hasil ini menunjukan bahwa responden rata-rata "sangat setuju" responden memilih dt-Peduli sebagai lembaga zakat pertama yang akan dituju ketika ingin membayar zakat.

\section{Lembaga Zakat yang Lebih Diketahui oleh Masyarakat Wilayah Bogor}

Berdasarkan jawaban muzaki dari BAZNAS Kota Bogor mengenai pengetahuan masyarakat terhadap lembaga zakat. Jawaban sangat setuju berjumlah 3 orang dengan persentase $15 \%$, muzaki yang setuju berjumlah 16 orang dengan persentase $80 \%$, dan muzaki yang kurang setuju 1 orang dengan preentase 5\%. Sedangkan jawaban muzaki dari dt-Peduli mengenai pengetahuan masyarakat terhadap lembaga zakat. Jawaban sangat setuju berjumlah 8 orang dengan persentase $40 \%$, dan muzaki yang setuju berjumlah 12 orang dengan persentase $60 \%$. Hasil ini menunjukan bahwasanya dari setiap responden lebih mengetahui lembaga zakat yang menjadi tempatnya membayar zakat

\section{Pengetahuan Muzaki Terhadap Program Layanan Mustahik}

Pada responden BAZNAS Kota Bogor Jawaban sangat setuju berjumlah 2 orang dengan persentase 10\%, muzaki yang setuju berjumlah 16 orang dengan persentase $80 \%$, dan muzaki yang kurang setuju 2 orang dengan persentase 10\%. Sedangkan, responden dt-Peduli dengan jawaban sangat setuju berjumlah 5 orang dengan persentase $25 \%$, dan muzaki yang setuju berjumlah 15 orang dengan persentase $75 \%$.

Dari hasil tersebut dapat disimpulkan bahwa masing-masing responden mengetahui program-program layanan mustahik yang terdapat pada kedua lembaga tersebut yaitu BAZNAS Kota Bogor dan dt-Peduli.

\section{Alternatif Pilihan Pembayaran Dana Zakat}

Pada responden BAZNAS Kota Bogor Jawaban sangat setuju berjumlah 3 orang dengan persentase 15\%, muzaki yang setuju berjumlah 16 orang dengan persentase $80 \%$, dan muzaki yang kurang setuju 1 orang dengan persentase 5\%. Sedangkan responden dt-Peduli, dengan jawaban sangat setuju berjumlah 6 orang dengan persentase $15 \%$, dan muzaki yang setuju berjumlah 15 orang dengan persentase $80 \%$.

Dari hasil tersebut dapat disimpulkan bahwa masing-masing responden memiliki alternative pilihan dalam pembayaran dana zakat yaitu BAZNAS Kota Bogor dan dt-Peduli.

\section{Adanya Sistem Keterbukaan dan Standarisasi Kebijakan Anggaran}

Jumlah responden BAZNAS Kota Bogor menjawab sangat setuju berjumlah 4 orang dengan persentase $20 \%$, dan muzaki yang setuju berjumlah 16 orang dengan persentase $80 \%$. Sedangkan jawaban responden dt-Peduli, sangat setuju berjumlah 4 orang dengan persentase $20 \%$, dan muzaki yang setuju berjumlah 11 orang dengan persentase $55 \%$, dan 5 orang menjawab kurang setuju dengan presntase $25 \%$.

Dari hasil tersebut dapat disimpulkan bahwa masing-masing responden menilai bahwa kedua lembaga tersebut yaitu BAZNAS Kota Bogor dan dt-Peduli memiliki sistem keterbukaan dan standarisasi mengenai kebijakan anggaran.

\section{Tersedianya Dokumen Anggaran dan Mudah Diakses}

Jumlah jawaban sangat setuju berjumlah 3 orang dengan persentase $15 \%$, dan muzaki yang setuju berjumlah 17 orang dengan persentase $85 \%$ berasal dari responden BAZNAS Kota Bogor. Sedangkan, awaban sangat setuju berjumlah 4 orang dengan persentase $20 \%$, dan muzaki yang setuju berjumlah 12 orang dengan persentase $60 \%$, dan 4 
orang menjawab kurang setuju dengan presntase $20 \%$ berasal dari dt-Peduli.

Dari hasil tersebut dapat disimpulkan bahwa masing-masing responden menilai bahwa kedua lembaga tersebut yaitu BAZNAS Kota Bogor dan dt-Peduli menyediakan dokumen anggaran yang mudah diakses.

Tersedianya Laporan Keuangan yang Diberikan Secara Berkala

Jumlah jawaban sangat setuju berjumlah 2 orang dengan persentase $10 \%$, dan muzaki yang setuju berjumlah 17 orang dengan persentase $85 \%$ dan responden yang menjawab kurang setuju berjumlah 1 orang dengan persentase 5\% berasal dari responedn BAZNAS Kota Bogor. Sedangkan, jawaban sangat setuju berjumlah 4 orang dengan persentase $20 \%$, dan muzaki yang setuju berjumlah 13 orang dengan persentase $65 \%$, dan 3 orang menjawab kurang setuju dengan presntase 15\% berasal dari dt-Peduli.

Dari hasil tersebut dapat disimpulkan bahwa masing-masing responden menilai bahwa kedua lembaga tersebut yaitu BAZNAS Kota Bogor dan dt-Peduli menyediakan dokumen anggaran yang mudah diakses.

\section{Terdapat Sistem Pemberian Informasi Kegiatan Penyaluran Dana Zakat}

Jumlah jawaban setuju berjumlah 19 orang dengan persentase $95 \%$ dan responden yang menjawab kurang setuju berjumlah 1 orang dengan persentase 5\% berasal dari responden BAZNAS Kota Bogor. Sedangkan, jawaban sangat setuju berjumlah 3 orang dengan persentase $15 \%$, dan muzaki yang setuju berjumlah 16 orang dengan persentase $80 \%$, dan 1 orang menjawab kurang setuju dengan presntase $5 \%$ bersal dari dt-Peduli.

Dari hasil tersebut dapat disimpulkan bahwa masing-masing responden menilai bahwa kedua lembaga tersebut yaitu BAZNAS Kota Bogor dan dt-Peduli memiliki sistem keterbukaan dan standarisasi mengenai kebijakan anggaran.

\section{Memberikan Uraian Pertanggung Jawaban Keuangan}

Jumlah jawaban sangat setuju berjumlah 6 orang dengan persentase $30 \%$, dan untuk jawaban setuju berjumlah 14 orang dengan persentase $70 \%$ berasal dari responden BAZNAS Kota Bogor. Sedangkan, jawaban sangat setuju berjumlah 4 orang dengan persentase $20 \%$, dan muzaki yang setuju berjumlah 15 orang dengan persentase $75 \%$, dan 1 orang menjawab kurang setuju dengan persentase $5 \%$ berasal dari dt-Peduli.

Dari hasil tersebut dapat disimpulkan bahwa masing-masing responden menilai bahwa kedua lembaga tersebut yaitu BAZNAS Kota Bogor dan dt-Peduli memberikan uraian pertanggungjawaban keuangan.

\section{Menjelaskan Uraian Jobdesk atau Tanggungjawab Per Divisi}

Jumlah jawaban sangat setuju berjumlah 5 orang dengan persentase $25 \%$, dan untuk jawaban setuju berjumlah 15 orang dengan persentase $75 \%$ berasal dari responedn BAZNAS Kota Bogor. Sedangkan, Jawaban sangat setuju berjumlah 5 orang dengan persentase $25 \%$, dan muzaki yang setuju berjumlah 13 orang dengan persentase $65 \%$, dan 2 orang menjawab kurang setuju dengan presntase $10 \%$ berasal dari dt-Peduli.

Dari hasil tersebut dapat disimpulkan bahwa masing-masing responden menilai bahwa kedua lembaga tersebut yaitu BAZNAS Kota Bogor dan dt-Peduli memberikan uraian pertanggungjawaban keuangan.

\section{Memberikan Informasi Tentang Inventarisasi Dana dan Pemeliharaan Sarana dan Prasarana}

Jumlah jawaban sangat setuju berjumlah 5 orang dengan persentase $25 \%$, untuk jawaban setuju berjumlah 14 orang dengan persentase $70 \%$, dan untuk responden yang menjawab kurang setuju berjumlah 1 orang dengan persentase $5 \%$ 
berasal dari responden BAZNAS Kota Bogor. Sedangkan, jawaban sangat setuju berjumlah 3 orang dengan persentase $15 \%$, dan muzaki yang setuju berjumlah 12 orang dengan persentase $60 \%$, dan 5 orang menjawab kurang setuju dengan persentase $25 \%$ berasal dari dt-Peduli.

Dari hasil tersebut dapat disimpulkan bahwa masing-masing responden menilai bahwa kedua lembaga tersebut yaitu BAZNAS Kota Bogor dan dt-Peduli memberikan informasi tentang inventarisasi dana dan pemeliharaan sarana dan prasarana.

\section{Memberikan Uraian Metode Kerja, Pengendalian Manajemen dan Kebijakan}

Jumlah jawaban sangat setuju berjumlah 4 orang dengan persentase $20 \%$, untuk jawaban setuju berjumlah 15 orang dengan persentase $75 \%$, dan untuk responden yang menjawab kurang setuju berjumlah 1 orang dengan persentase $5 \%$ berasal dari responden BAZNAS Kota Bogor. Sedangkan, jawaban sangat setuju berjumlah 3 orang dengan persentase $15 \%$, dan muzaki yang setuju berjumlah 14 orang dengan persentase $70 \%$, dan 5 orang menjawab kurang setuju dengan presntase $15 \%$ bersal dari dt-Peduli.

Dari hasil tersebut dapat disimpulkan bahwa masing-masing responden menilai bahwa kedua lembaga tersebut yaitu BAZNAS Kota Bogor dan dt-Peduli memberikan uraian metode kerja, pengendalian manajemen dan kebijakan.

\section{Penerapan Transparansi dan Akuntabilitas Pada BAZNAS Kota Bogor}

Menurut hasil wawancara yang dilakukan oleh peneliti kepada salah satu staff bagian keuangan di BAZNAS Kota Bogor yaitu Ibu Widya Wuri Handayani, Adm. Penerapan transparansi dan akuntabilitas yang dilakukan oleh BAZNAS Kota Bogor salah satunya adalah dengan menerapkan media SIMBA atau sistem zakat online. Tujuan digunakannya media SIMBA atau sistem zakat online oleh BAZNAS Kota Bogor adalah untuk meningkatkan sistem pengelolaan dana zakat agar lebih transparan dan akuntabel. Media SIMBA atau sistem zakat online ini digunakan khusus untuk bagian funding.

Selain itu, salah satu cara yang dilakukan oleh BAZNAS Kota Bogor dalam menerapkan transparansi dan akuntabilitasnya adalah dengan membuat dan mempublikasikan hasil laporan keuanganya ke publik. Hal ini dilakukan guna, memberikan informasi kepada masyarakat terutama muzakki BAZNAS Kota Bogor mengenai pengelolaan dana zakat

Semua bentuk informasi mengenai pengelolaan dana zakat telah di publikasikan di media sosial ataupun media cetak. Media sosial yang digunakan oleh BAZNAS Kota Bogor yaitu salah satunya adalah Web BAZNAS Kota Bogor, WhatsApp, Instagram, Facebook dan Twitter.

Penerapan Transparansi dan Akuntabilitas Pada dt-Peduli

Menurut hasil wawancara yang dilakukan oleh peneliti kepada kepala pimpinan dt-Peduli yaitu bapak Fatah Fauzi, Lc. Penerapan transparansi dan akuntabilitas yang dilakukan oleh dtPeduli salah satunya adalah dengan menerapkan sistem ZEIN. ZEIN merupakan salah satu nama sistem yang tujuannya adalah untuk meningkatkan sistem pengelolaan dana zakat agar lebih transparan dan akuntabel.

Sistem ZEIN ini digunakan khusus untuk bagian funding. Selain itu, salah satu cara yang dilakukan oleh dt-Peduli dalam menerapkan transparansi dan akuntabilitasnya adalah dengan membuat dan mempublikasikan hasil laporan keuanganya ke publik. Akan tetapi, dikarenakan dt-Peduli cabang Bogor tersentral oleh pusat untuk masalah pemberian informasi maka semuanya dilakukan oleh dt-Peduli pusat. Dt-Peduli cabang Bogor hanya menyerahkan laporan keuangannya kepada pusat dan yang akan mempublikasikannya adalah pusat. 
Media sosial yang digunakan oleh dtPeduli hampir sama dengan BAZNAS KOTA Bogor yaitu salah satunya adalah Web dt-Peduli cabang Bogor, WhatsApp, Instagram, Facebook dan Twitter. Hanya saja yang membedakan adalah pada media cetak. Pada dt-Peduli media cetak yang digunakan adalah majalah SWADAYA, sedangkan untuk BAZNAS Kota Bogor menggunakan koran dan buku.

\section{Hasil Uji Beda}

Melalui uji perbedaan independent Sample $t$-Test, terbukti bahwa adanya perbedaan nilai dalam penerapan transparansi dan akuntabilitas antara BAZNAS Kota Bogor dan dt-Peduli. Untuk penerapan transparansi nilai $\mathrm{t}(38)=$ 0,$518 ; p<0,05$. Nilai pada Sig. (2 tailed) yaitu 0,608 yang artinya bahwa nilai ini lebih besar dari 0,05 $(0,608>0,05)$.

Sehingga kesimpulannya adalah tidak terdapat perbedaan yang signifikan pada nilai penerapan transparansi antara BAZNAS Kota Bogor dan dt-Peduli. Sedangkan untuk penerapan akuntabilitas nilai $\mathrm{t}(38)=-1,291 ; p<0,05$. Nilai pada Sig. ( 2 tailed) yaitu 0,205 artinya nilai ini lebih besar dari 0,05 $(0,205>0,05)$. Pada kolom Mean Difference, menunjukkan selisih rata-rata dari kedua kelompok. Terlihat terdapat tanda minus, yang menandakan bahwa kelompok kedua atau penerapan transparansi dan akuntabilitas di BAZNAS Kota Bogor mempunyai ratarata yang lebih bersar dari pada penerapan transparansi dan akuntabilita pada dt-Peduli.

\section{KESIMPULAN DAN IMPLIKASI}

Berdasarkan hasil penelitian yang telah dilakukan, maka dapat disimpulkan bahwa:

1. Penerapan transparansi dan akuntabilitas yang dilakukan oleh BAZNAS Kota Bogor salah satunya adalah dengan menerapkan media SIMBA atau sistem zakat online pada sisi funding, mempublikasikan laporan keuangan secara mandiri melalui koran atau buku dari sisi keuangan. Sedangkan dt-Peduli, pada sisi funding sistem yang digunakan adalah sistem ZEIN. Pada sisi keuangan untuk menunjukan sikap transparansi dan akuntabilitas dengan cara mempublikasikan laporan keuangan pada majalah SWADAYA.

2. Berdasarkan hasil uji perbedaan Independent Sample T-test, diketahui Untuk penerapan transparansi nilai $\mathrm{t}$ $(38)=-0,518 ; p<0,05$. Nilai pada Sig. (2 tailed) pada tabel 4.9 yaitu 0,608 yang artinya bahwa nilai ini lebih besar dari $0,05 \quad(0,608>0,05)$. Kesimpulannya adalah tidak terdapat perbedaan yang signifikan pada nilai penerapan transparansi antara BAZNAS Kota Bogor dan dt-Peduli. Sedangkan untuk penerapan akuntabilitas nilai $\mathrm{t}$ (38) $=-1,291 ; p<0,05$. Nilai pada Sig. ( 2 tailed) yaitu 0,205 artinya nilai ini lebih besar dari 0,05 (0,205>0,05). Kesimpulannya adalah tidak terdapat perbedaan yang signifikan pada nilai akuntabilitas antara BAZNAS Kota Bogor dan dt-Peduli

\section{DAFTAR PUSTAKA}

Dauky, Abdul Hafiz \& Irsyad lubis. (2015). Analisis Faktor-faktor Penyebab Keengganan Masyarakat Membayar Zakat Melalui BAZIS atau LAZ di Kota Medan (Studi Kasus: Masyarakat Kecamatan Medan Tembung). Jurnal Ekonomi \& Keuangan, Vol. 3 No. 4, hal: 242.

Maani, Dt. Karjuni. (2009). Transparansi dan Akuntabilitas dalam Pelayanan Publik. Demokrasi, Vol. VIII. No. 1 tahun 2009, hal: 42.

Dwiyanto, Agus. (2006). Mewujudkan Good Governance Melalui Pelayanan Publik. Yogyakarta: UGM Press.

Endahwati, Yosi Dian. (2014). Akuntabilitas Pengelolaan Dana Zakat, Infak dan Shadaqah (ZIS). Jurnal Ilmiah 
Akuntansi dan Humanika JINAH. Vol. 4 No. 1 Singaraja, Desember 2014. ISSN 2089-3310, 1359, hal: 1359.

Fitri, Indri Yuliantri \& Asma Nur Khoiriyah . (2016). Pengaruh Kepuasan Muzakki, Transparansi dan Akuntabilitas Pada Lembaga Amil Zakat Terhadap Loyalitas Muzakki (Studi Persepsi Pada LAZ Rumah Zakat). Islamiconomic: Jurnal Ekonomi Islam, Vol. 7 No. 2. P-ISSN: 2085-3696, E-ISSN: 2541-4127. Juli - Desember 2016 , 207, hal: 207.

Hafidhuddin. (2011). Peran Strategis Organisasi Zakat dalam Menguatkan Zakat di Dunia. Al-Infaq Jurnal Ekonomi Islam. Vol 2, No 1, hal: 4-7.

Kusmiati, Mia. (2015). Membangun Kesehatan Organisasi Institusi Pendidikan Dokter: Sebuah Transformasi Menuju Akuntabilitas Sosial. Mimbar, Vol. 31.1. PP. 123134, hal: 486.

Mardiasmo \& Sopanah (2003). Pengaruh Partisipasi Masyarakat dan Transparansi Kebijakan Publik Terhadap Hubungan Antara Pengetahuan Dewan Tentang Anggaran Dengan Pengawasan Keuangan Daerah. Jurnal dan Prosiding SNA, hal: 77.
Munjiah. (2107). Pengaruh Akuntabilitas Pelayanan dan Transparansi Zakat Terhadap Kepuasan Muzakki (Studi Kasus BAZNAS Provinsi Banten). Jakarta: UIN Syarif Hidayatullah, hal: 28.

Nazir, Moh. (2011). Metode Penelitian. Bogor: Penerbit Ghalia Indonesi, hal: 54.

Nikmatunayah, Marliyati. (2015). Akuntabilitas Laporan Keuangan Lembaga Amil Zakat di Kota Semarang. MIMBAR, Vol. 31. No. 2 (Desember, 2015). ISSN: 485-494, hal: 486.

Sudewo, Eri. (2004). Manajemen Zakat. Ciputat: Institut Manajemen Zakat, hal: 190.

Sugiyono. (2015). Metode Penelitian Kuantitatif Kualitatif dan $R$ \& D. Bandung: Alfabeta, hal: 80.

Sulistoni. (2003). Fiqh Korupsi : Amanah vs Kekuasaan. Nusa Tenggara Barat: SOMASI, hal: 56.

Thoha, Miftah. (2002). Perilaku Organisasi Konsep dasar dan Aplikasinya . Jakarta: rajawali Grafindo Persada, hal: 132 .

Triyuwono, Iwan. (2000). Organisasi dan Akuntansi Syariah. Yogyakarta: LKIS. 